IRA-International Journal of Applied Sciences ISSN 2455-4499; Vol.06, Issue 03 (2017)

Institute of Research Advances

Pg. no. 70-79

https://research-advances.org/index.php/IRAJAS

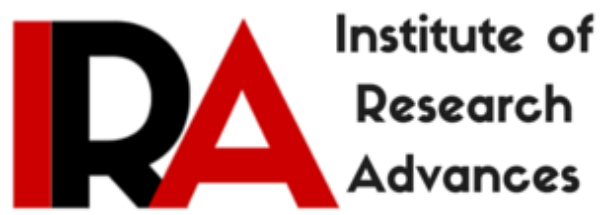

\title{
Nutritional Deficiency Diseases in School Children Rural Areas of Mangaraipattai Village Musiri Taluk, Tamil Nadu
}

C.Maruthanayagam ${ }^{1}$, R. Mahalakshmi ${ }^{2}$

${ }^{1,2}$ Dept. of Zoology, Aringar Anna Govt. College, Musiri. 621211, India.

Type of Review: Peer Reviewed.

DOI: http://dx.doi.org/10.21013/jas.v6.n3.p1

How to cite this paper:

Maruthanayagam, C., \& Mahalakshmi, R. (2017). Nutritional Deficiency Diseases in School Children Rural Areas of Mangaraipattai Village Musiri Taluk, Tamil Nadu. IRA-International Journal of Applied Sciences (ISSN 2455-4499), 6(3), 70-79. doi:http://dx.doi.org/10.21013/jas.v6.n3.p1

(C) Institute of Research Advances

\section{(cc) EY-NC}

This work is licensed under a Creative Commons Attribution-Non Commercial 4.0 International License subject to proper citation to the publication source of the work.

Disclaimer: The scholarly papers as reviewed and published by the Institute of Research Advances (IRA) are the views and opinions of their respective authors and are not the views or opinions of the IRA. The IRA disclaims of any harm or loss caused due to the published content to any party. 


\section{ABSTRACT}

An intervention study was conducted among 518 school going children with an objective to study the nutritional deficiency disease in Mangaraipettai village. Anemia is one of the major prevalent nutritional deficiencies in the world, and more than half of the population in India is anemic, the prevalence of anemia is very high among school going children, anemia leads to poor pregnancy outcome, impaired school performance, decreased work productivity and other adverse effects comes. This study was conducted to assess the prevalence of anemia, underweight, vitamin A deficiency, parasite infection, dental caries, stunting growth and some social factor including drinking water sources, intake of leafy vegetable among school going children 4 year old to 14 years of age, and the results found was $74.5 \%$ of students are anemia. The other results were discussed.

Keywords: Anemia, hemoglobin, underweight, vitamin disorder

\section{Introduction}

Health and nutrition in early stages of human life determine, to a great extent, the physical and mental well being of a person. In a developing country like India poverty undoubtedly constitutes a major factor for malnutrition in children, but lack of awareness of what constitutes balanced diet is also a factor, which needs to be considered. School going children of different age groups from a vulnerable population where studies in respect of nutritional deficiencies could be done with respect in the income groups of the prevents. There is a growing concern over the child health all over the world with rapid economic growth and social changes. Major determines of health status is an adult is their nutritional status in childhood.

Protein Energy malnutrition is the most important nutritional problem globally which is more severe in third world countries offering children of under five age category $20-80 \%$ of primary school children are suffering from nutritional deprivation (Shiva Prakash and Ranjit Baby Joseph 2014). Assessment of nutritional status of this segment of population is essential for improving the overall health. Recent study by NFHS - 3 has not reported on nutritional status of school age children. (Fazili - 2012)

The term malnutrition refers to both under - nutrition and over - nutrition and over nutrition. Good nutrition provides stronger immune system, better health, and productivity. According to Vandana Sati (2012) various forms of malnutrition including both macro and micronutrient deficiencies affect a large segment of population in India.

\section{Statement of the Problem}

Prevalence of anemia, vitamin deficiency disease among school going children (below12 Years of age) in selected one village namely Mangaraipettai, this village is Musiri Taluk and Tiruchirappalli District, Tamil Nadu. It is situated at a distance of $5 \mathrm{Km}$ from the college (Musiri) and has a population of 3.5 lakhs. No reliable estimation of nutritional deficiency disease is available from the mentioned area

\section{Objective of the Study}

To determine the prevalence of Anemia, identify Anthropometric Indies, Identify the Hemoglobin level and vitamin disorder in Mangaraipettai village.

\section{Materials and Methods}

Research Methodology

Research approach: Quantitative Research Approach. 
Research Design: A cross - sectional survey was used in this study..

\section{Method of Data Collection}

After obtaining authorized consent from village Panchayat head, the village (Mangaraipettai) was united and the data was collected using readymade problem. All the children between 4 13 Years of age were included in the study. The data was collected by interviewing and examining the children with the help of parents. The children were assessed for nutritional status by clinical examination and by measuring Height $(\mathrm{cm})$, Weight $(\mathrm{Kg})$ which was compared with the NCHS (National Center for Health Statistics), Standards given by ICMR (Indian Council of Medical Research). Weight was measured using a floor type weighing scale with due respect to the standardization of the equipment and procedure. The measurements are taken to the nearest $0.5 \mathrm{Kg}$. Height was measured using a measuring tape applied to the wall. The measurements are taken with children bare foot with their back of heels, buttocks, and head touching the wall. Reading are taken to the nearest $0.5 \mathrm{Cm}$. The importance signs looked for during clinical examination are Pallor, Hair changes (Sparse hair / de pigmentation of hair) Eye changes (conjunctiva xerosis, biot's spots, cornel xerosis, cornealulceration) parasitic infection teeth changes (enamel mottling, caries, delayed eruption) skeletal changes, Goiter, Skin changes ( dry Skin, flaky paint dermatosis) (Shiva Prakash and Joseph - 2014) and some social parameter like, food habits, drinking water sources, mental health, Anemic body index (BMI) was calculated and Blood hemoglobin was estimated by the Gyanametremoglobin methods.

\section{Results and Discussion}

The general socio economic and health characteristics of subjects are shown in Tables (1- 4) out of 518 children, majority girls ( $72.7 \%$ ) of the mothers were literate $63.12 \%$. Worm infestation was present in $16.4 \%$, Dental cirrhosis was present in $41.1 \%$, stunting group was present in $37 \%$ and vitamin A deficiency $28.3 \%$ was recorded. (Table 4).

Prevalence of vitamin A deficiency contributes to diarrheal disease, respiratory infection and measles etc., vitamin A deficiency disorder spectrum has the unique distinction of being one of the most important causes of preventable blindness the world over, and xerophthalmia still remains a problem in the developing countries. The present study eye changes noted in the form of conjunctiva xerosis and bitot's spots (13.1\%) that included 14 boys and 54 girls. Kmath., et al., (2012) reported that the prevalence of ocular morbiding among school going children (6-15 years) in Kolar district of commonest ocular morbidity, bitotspot and conjunctiva xerosis. In a study at rural on Maharastitra by Jjayant (2011) 25.58\%. Vitamin A deficiency was reported during the study period. Vitamin A deficiency recoded during the observed period (28.3\%). These children may affect the growing character, and also it is a public health problem in the country. Vitamin A is important for promoting growth of the child and building immunity and resistance to diseases, the observation of most of children.

Tables (5-8) depicts that children was significantly associated with prevalence of anemia at 0.5 level of significance, Among the 518 children mild anemia $37.67 \%$ and severe anemia $6.37 \%$ were observed, where as mother educational qualification, underweight were significantly associated with prevalence of anemia among sample at 0.05 level of significance. Anemia defined as Hemoglobin concentration is low, the established cut-off level is a major public health problem with major consequences for human health as well as social and economic development (Al.mekk lafi et al., 2008). However, little progress has been reported in the control of anemia focus on adolescent and teenage girls are required to reduce prevalence of anemia and could be integrated with participatory nutrition education.

This study the prevalence pattern of dental caries varies with age, sex socio economic status and oral hygiene practices. In our study teeth changes were noted in the form of dental caries in 213 (41.1\%) Saravanan et al., 2003 from Pondicherry reported a prevalence of dental caries of $44.4 \%$ in 5 years age group and $22.3 \%$ in 12 years age group. 
Hair changes in the form of sparse hair or depigmental or lusterless here were seen in 88/518 (16.9\%) who included 41 boys and 47 girls and was more in the age 7 to14 years. Sivaprakash and Joseph (2014) assessed the nutritional status of school children in Mandya District Karnataka ,and found that majority of the children had lack of depigment hair (3.9\%).

This study was conducted to assess the prevalence of anemia, underweight, vitamin A deficiency, parasite infection, dental caries, stunting growth and some social factor including drinking water sources, intake of leafy vegetable among pre- school going children up to 14years of age of, and the results found was $74.5 \%$ of students are anemia, among the results ngs shows that $23.48 \%$ of sample were male and $26.25 \%$ of sample were female. Similarly stunting growth, vitamin A deficiency and parasite infection underweight shows $37 \%, 28.3 \%, 16.4 \%$ and $41.89 \%$ respectively. Social factor like intake of leafy vegetable recorded $43.8 \%$ and another factor mother education was recorded up to $63.12 \%$ (Table- 8 ).

\section{Suggestion}

The present study reveals that, the rural school going children of Mangaraipattai village, Musiri taluk were suffering from different grade of malnutrition, According to Shivaprakash and Ranjit Baby josep (2014) suggestion to give mothers of these children should be educated about the importance of balanced diet, consumption of food like cereals, pulses, green leafy vegetables, roots and tubers, sugar and jiggery, fats and oil , milk and milk products, fruits etc., should be promoted. Similarly, government should introduce awareness programme through community participation, involvement of NGO'S and other sectors regarding affordable but nutrition food.

\section{Acknowledgement}

Authors thanks this project was supported by UGC. New Delhi funded for minor project

\section{References}

1. AI-Mekhlafi MH, Surin J,Atiya AS, Ariffin WA,Mohammed Mehdy AK, Che Abdullah H. 2008 Transactions of the Royal society of tropical Medicine and Hygiene , 102:1046-1052.

2. Bandopoghyay D.A., 1988.Nutition Survey of school children, Navi Nagar Mumbai.Medical journal and Forum India. 44(1):31-46.

3. Chowdhary .S .D, Chakraboraty T, Ghosh T.1988 Prevalence of under nutrition in sandal children of Puriliya district West Bengal. Indian pediatrics.45 (1):43-46.

4. Fazili A, Mir A, Pandit IM et al 2012. Nutritional Status of School Age Children (5-14 years) in a Rural Health Block of North India (Kashmir) Using WHO Z-Score System. Online Journal of Health and Allied Scientific Reports.11-3.

5. Hashizume M,Kunii O, Sasaki S, Shimode T,Wakai, S, Mazhtova Z, Dauletbeav D, Yamashiro Y, Chiba M. 2003.Anemia and iron deficiency among school children in the Aral Sea region, Kazakhstan. J.Food Sci. Nutr, 55:37-47.

6. Hashizume M, Chiba M, Chiba M, Shinohara A, Lwabuchi S, Sasaki S, Shimode T,Kunii O Caypil W,Daultbaes D Alnazarova A 2005. Anaemia, Iron Deficiency and vitamins a status among school-aged children in rural Kazakhstan. Public Health Nutr., 8:564-571.

7. Hashizume M,Kunii O,Sasaki S, Shimode T,Wakai S,Mazhitova z,Dauletbaev D, Caypil W, Aidiyarova M, Farmer A, Yamashiro Y, Chiba M.2003.Anemia and iron deficiency among schoolchildren in the Aral Sea region, Kazakhstan J.Trop. Pediatric. 49:172-177. 
8. Hashizume M,Shimode T,Sasaki S,Kunii O,Caypil W, Dauletbaev D, Chibaa M 2004. Anemia in relation to low bioavailability of dietary iron among school-aged children in the Aral Sea region, Kazakhstan. Int. J FOOD Sci. nutr, 55:37-43.

9. Kamath. P, Gwn Prasa DS,Deepthi R,Mwninrayans C.,2012 Prevalence of ocular Morbidity among school going children (6-15) in rural area of Karnataka, south India. Int pharm Biomed Res. 3(4):209-212.

10. Mendhi GK,Baruua A,Mahanta J. 2006. Growth and Nutritional Status of School age Children in Tea garden Workers of Assam. J human E.col.19 (2):83-83.

11. Mitra M,Kumar PV,Chakraboraty S,Bharati P 2007. Nutritional Status of Kamr Tribal Chhattisgarh. Indian Pediatrics. 74(4):381-384.

12. National Family Health SuRVEY (NFHS-3)(2000)-Anemia among women and children. Mumbai: International Institute for Population Sciences.

13. National Family Health Survey (NFHS-3)2005-06, Nutrition in India, Ministry of Health and Family Welfare Government on India.

14. Rajaratnam. J.,Abel. R., Asokan, J.S. and Jonathan, P.2000. Prevalence of anemia among adolescent girls of rural Tamil Nadu. Indian pediat, 27: $532-536$.

15. Rakesh Kumar 2014. Anemia A Common Health Problem, Consequence and Diet Management among Young Children and Pregnant woman. Biological Forum -An International Journal 6(1):27-32.

16. Shivaprakash. N.C and Ranjit Baby josep. 2014. Nutritional status of rural school-age children (6-12 years) of Madhya District Karnataka. International Journal of scientific study. Vol.2. 39-42.

17. Saravanan .S, Anwradha K.P,Bhaslear D.J. 2003.Prevalence of dental Caries and treatment need among school going children of Pondicherry, India. J Indian soc peded .prev. Dent.21 $(1): 1-2$.

18. World Health Organization Report. 2002. The annual Report of World Organization: Reducing risks, promoting health life .Geneva

19. World Health Organization. Anemia. WHO.2010. 
Table: 1 Age wise distribution of children.

\begin{tabular}{|c|c|c|c|}
\hline $\begin{array}{c}\text { Age group } \\
\text { (years) }\end{array}$ & No of children \% & Boys & Girls \\
\hline $4-5$ & $8(1.5)$ & $3(2.12)$ & $5(1.326)$ \\
\hline $5-6$ & $34(6.56)$ & $22(64.7)$ & $12(35.29)$ \\
\hline $6-7$ & $31(5.98)$ & $14(45.16)$ & $17(54.83)$ \\
\hline $7-8$ & $38(7.33)$ & $19(50.0)$ & $19(50.0)$ \\
\hline $8-9$ & $30(5.70)$ & $18(60.0)$ & $12(40.0)$ \\
\hline $9-10$ & $21(4.09)$ & $16(76.1)$ & $12(60.0)$ \\
\hline $10-11$ & $20(3.86)$ & $8(40.0)$ & $82(9425)$ \\
\hline $11-12$ & $87(16.79)$ & $5(5.74)$ & $57(78.0)$ \\
\hline $12-13$ & $73(15.25)$ & $16(21.9)$ & $36(67.90)$ \\
\hline $13-14$ & $53(10.23)$ & $17(32.07)$ & $110(89.43)$ \\
\hline $14-15$ & $123(27.40)$ & $13(10.56)$ & $(\mathbf{2 9 . 1 5})$ \\
\hline Total (\%) & $\mathbf{5 1 8 ( 1 0 0 )}$ & & \\
\hline
\end{tabular}


Table :2 Sexwise distribution of children.

\begin{tabular}{|c|c|c|}
\hline Sex & Number of children & Percentage \\
\hline Boys & 141 & 27.200 \\
\hline Girls & 377 & 72.77 \\
\hline Total & 518 & 100 \\
\hline
\end{tabular}

\section{Table:3}

Grading of anemia

\begin{tabular}{|c|c|c|}
\hline S .No & Grade & Scale (hemoglobin level in $\mathbf{~ m}$ /dl \\
\hline 1 & Mild & $\begin{array}{c}\text { 10 lower climate of normal } \\
\text { hemoglobin }\end{array}$ \\
\hline 2 & Moderate & $8-10$ \\
\hline 3 & Severe & $<8$ \\
\hline 4 & Life threatening & Life threatening \\
\hline 5 & Death & Death \\
\hline
\end{tabular}

Common Terminology Criteria for Adverse Events (CTCAE) 
IRA-International Journal of Applied Sciences

\begin{tabular}{|c|c|c|c|c|c|c|c|c|c|c|c|c|c|c|}
\hline \multirow[t]{2}{*}{ Age } & \multirow[t]{2}{*}{ children } & \multirow[t]{2}{*}{ Weight } & \multirow[t]{2}{*}{ Height } & \multirow{2}{*}{$\begin{array}{r}\text { Stunting } \\
\text { growth } \\
\%\end{array}$} & \multicolumn{3}{|c|}{ Drinking water sources } & \multirow{2}{*}{$\begin{array}{l}\text { Dental } \\
\text { caries }\end{array}$} & & & \multirow{2}{*}{$\begin{array}{r}\text { Mother } \\
\text { education }\end{array}$} & \multirow{2}{*}{$\begin{array}{l}\text { Intake of } \\
\text { Leafy } \\
\text { vegetable }\end{array}$} & \multirow{2}{*}{$\begin{array}{l}\text { Parasite } \\
\text { infection }\end{array}$} & \multirow{2}{*}{$\begin{array}{l}\text { Eye } \\
\text { color } \\
\text { change }\end{array}$} \\
\hline & & & & & $\begin{array}{r}\text { Well } \\
\text { water } \\
\text { consumer }\end{array}$ & $\begin{array}{r}\text { River } \\
\text { water } \\
\text { consumer }\end{array}$ & $\begin{array}{r}\text { Both } \\
\text { water } \\
\text { consumer }\end{array}$ & & $\begin{array}{r}\text { Hair } \\
\text { Changes }\end{array}$ & $\begin{array}{r}\text { Vitamin } \\
\text { Deficiency }\end{array}$ & & & & \\
\hline \multirow[t]{2}{*}{4} & Boys (3) & $13.6-15.1$ & $3.9-4$ & 33.0 & 3 & - & - & 33 & 0 & 33 & 100 & 100 & - & - \\
\hline & Girls[5] & $10-13.2$ & $3.11-4.0$ & 40.0 & 4 & 1 & & 40 & 0 & 40 & 100 & 40 & 20 & - \\
\hline \multirow[t]{2}{*}{5} & Boys[22] & $12-18$ & $3.7-4.7$ & 13.6 & 9 & 13 & - & 100 & 4 & 31.8 & 18.1 & 36 & - & 9.09 \\
\hline & Girls[12) & $14-18$ & $3.4-3.9$ & 16.6 & - & 12 & - & 25 & 5 & 66.6 & 33.3 & 50 & - & 8.33 \\
\hline \multirow[t]{2}{*}{6} & Boys[14] & $9.6-23.7$ & $2.11-4.9$ & 7.1 & 3 & 10 & 1 & 35.7 & 3 & 42.8 & 57.1 & 20 & - & 21.42 \\
\hline & Girls[17) & $12-29.1$ & $3.2-4.3$ & 29.4 & 3 & 13 & 1 & 64.7 & 3 & 47.0 & 76.4 & 76 & 17.6 & 23.5 \\
\hline \multirow[t]{2}{*}{7} & Boys[19] & $16-24$ & $3.7-4.9$ & 21.05 & 2 & 7 & - & 36.8 & 3 & 22.0 & 100 & 77 & 2.4 & 52.6 \\
\hline & Girls[19] & $13.7-31$ & $3.7-4.7$ & 31.5 & 3 & 16 & - & 36.8 & 5 & 36.6 & 63.1 & 57 & 5.2 & - \\
\hline \multirow[t]{2}{*}{8} & Boys[18] & $14-25$ & $3.5-50$ & 36.8 & 2 & 15 & - & 72.2 & 2 & 33.3 & 66.6 & 33 & 15.6 & - \\
\hline & Girls[12) & $16.3-23$ & $3.7-50$ & 25.0 & 2 & 9 & 1 & 66.6 & 4 & 8.3 & 58.3 & 66 & 50.0 & 16.6 \\
\hline \multirow[t]{2}{*}{9} & Boys $(16)$ & $17-29$ & $3.7-50$ & 50.8 & 2 & 14 & - & 62.5 & 3 & 25.0 & 81.2 & 25 & 25.0 & 12.5 \\
\hline & Girls[5] & $20-23$ & 4.54 & 40 & 1 & 4 & - & 60 & 4 & 40.0 & 80.0 & 20 & 40.7 & - \\
\hline \multirow[t]{2}{*}{10} & Boys $[8]$ & $22-37$ & $41-50$ & 12.5 & 4 & 4 & - & 37.5 & 0 & 25.0 & 87.5 & 50 & 12.5 & - \\
\hline & Girls[12) & $17.3-24$ & $39-50$ & 25.0 & 5 & 7 & - & 83.3 & 2 & 8.3 & 75 & 50 & - & 18.3 \\
\hline \multirow[t]{2}{*}{11} & Boys(5) & $\begin{array}{r}16.9- \\
27.412 .5\end{array}$ & $49-52$ & 0 & 5 & - & - & 40 & 3 & 20.0 & 40 & 40 & - & 20 \\
\hline & Girls[82] & $18-51$ & $4.1-57$ & 41.6 & 41 & 38 & 3 & 39.0 & 2 & 37.8 & 62.1 & 54 & - & 14.6 \\
\hline \multirow[t]{2}{*}{12} & Boys[16] & $22-33$ & $4.2-54$ & 12.5 & 15 & - & 1 & \begin{tabular}{|l|}
43.7 \\
\end{tabular} & 5 & 12.5 & 68.7 & 62 & - & 12.5 \\
\hline & Girls[57) & $20-47$ & $4.1-5.11$ & 54.3 & 21 & 36 & - & 28.0 & 11 & 38.5 & 68.4 & 50.8 & 47.32 & 24.5 \\
\hline \multirow[t]{2}{*}{13} & Boys[17) & $23-56$ & $4.4-66$ & 19.6 & 17 & - & - & 58.8 & 10 & 23.5 & 58.8 & 41.1 & - & 11.7 \\
\hline & Girls[36) & $19-54$ & $4.2-54$ & 32.3 & 8 & 24 & 4 & 36.1 & 4 & 36.1 & 56.3 & 30.5 & 36.1 & 8.3 \\
\hline \multirow[t]{4}{*}{14} & Boys[13) & $27-41$ & $4.5-6.2$ & 0 & 9 & 4 & - & 38.4 & 8 & 7.6 & 40.1 & 4 & - & 7.6 \\
\hline & Girls[0] & $22-5.8$ & $4.3-6.8$ & 56.3 & 11 & 9 & 5 & 20.9 & 7 & 20.0 & 70.9 & 32 & 20 & 0.14 \\
\hline & Total & & & 192 & & - & - & 213 & 88 & 147 & 327 & 227 & 85 & 68 \\
\hline & $\%$ & & & 37.0 & & - & - & 41.1 & 16.9 & 28.3 & 63.12 & 43.8 & 16.4 & 13.1 \\
\hline
\end{tabular}

Table - 4 : Prevalence of Nutritional Deficienci 
Table:5 Different grade of anemic level and percentage of study sample.

\begin{tabular}{|c|c|c|c|c|}
\hline Total & $\begin{array}{c}\text { Normal } \\
9-13\end{array}$ & $\begin{array}{c}\text { Mild anemia } \\
7-8-9\end{array}$ & $\begin{array}{c}\text { Severe anemia } \\
<7\end{array}$ & Total \\
\hline $\begin{array}{c}\text { Male } \\
141\end{array}$ & $76.59 \%$ & $16.39 \%$ & $7.0921 \%$ & $100 \%$ \\
\hline $\begin{array}{c}\text { Female } \\
377\end{array}$ & $79.04 \%$ & $20.159 \%$ & $6.100 \%$ & $100 \%$ \\
\hline $\begin{array}{c}\text { Total } \\
518\end{array}$ & $74.51 \%$ & $37.67 \%$ & $6.37 \%$ & $100 \%$ \\
\hline
\end{tabular}

Table:6 Demographic of Calculated chi square test.

\begin{tabular}{|c|c|c|c|c|}
\hline $\begin{array}{c}\text { Demog } \\
\text { raphic } \\
\text { value }\end{array}$ & df & $\begin{array}{c}\text { Calculation } \\
\boldsymbol{\chi} \text { 2 value }\end{array}$ & $\begin{array}{c}\text { Table } \chi^{2} \\
\text { value }\end{array}$ & \multicolumn{1}{|c|}{ Remark } \\
\hline $\begin{array}{c}\text { Mother } \\
\text { education } \\
\text { qualification }\end{array}$ & 2 & 35.65 & \multirow{2}{*}{5.99} & $\begin{array}{l}\text { Signification at } \\
0.05\end{array}$ \\
\hline $\begin{array}{c}\text { Anemia } \\
\text { level }\end{array}$ & 2 & 124.5 & & \\
\hline $\begin{array}{c}\text { Under } \\
\text { weight }\end{array}$ & 2 & 36.35 & & \\
\hline
\end{tabular}


Table:7 Anthropometric indicators among the study population (BMI)

\begin{tabular}{|l|c|c|c|c|}
\hline BMI-for age & Male & Percentage & Female & Percentage \\
\hline Under weight & 58 & 38.4 & 113 & 36.2 \\
\hline Normal & 83 & 54.9 & 218 & 21.5 \\
\hline $\begin{array}{l}\text { At risk of } \\
\text { over weight }\end{array}$ & 10 & 10.6 & 36 & 9.8 \\
\hline
\end{tabular}

Table:8 Different characters and percentage of study samples.

\begin{tabular}{|l|c|c|}
\hline \multicolumn{1}{|c|}{ Characters } & Frequency & Percentage \\
\hline No anemia & 386 & 74.5 \\
\hline Anemia & 132 & 25.4 \\
\hline Stunting growth & 192 & 37.0 \\
\hline $\begin{array}{l}\text { Vitamin A } \\
\text { deficiency }\end{array}$ & 147 & 28.3 \\
\hline Parasite infection & 85 & 16.4 \\
\hline $\begin{array}{l}\text { Intake of leafy } \\
\text { vegetable }\end{array}$ & 227 & 43.8 \\
\hline Mother education & 327 & 63.12 \\
\hline Under weight & 217 & 41.89 \\
\hline
\end{tabular}

